\title{
THE PHYSICIAN'S ROLE IN RECOGNIZING PHYSICAL ABUSE OF CHILDREN
}

Health Center Siroki Brijeg Bosnia and Herzegovina

\author{
Matija Mikulic \\ Health Center \\ Dr. J. Grubišića 11 \\ 88220 Siroki Brijeg \\ Bosnia and Herzegovina \\ matijamikulic@gmail.com \\ Tel.: + 38763422166 \\ Fax.: + 38736704936
}

Received: December 11, 2012

Accepted: January 28, 2013

Copyright (C) 2013 by

University Clinical Center Tuzla.

E-mail for permission to publish:

paediatricstoday@ukctuzla.ba
Matija MIKULIC, Kristina JURISIC

Physicians are in frequent and regular contact with children and families through regular check-ups of pregnant women, newborns, and children of preschool and school-age. Therefore, physicians are in a unique position to effectively detect risk or detect abuse and neglect in good time and initiate the process of providing assistance to protect the child and allow him/her recovery and further undisturbed development. This paper discusses definitions of physical abuse, risk factors and the most common forms of physical abuse, the differences between accidental and non-accidental injuries, and the protocol for professional action in cases of child abuse. Conclusion - Physical abuse of children is a common occurrence, and it carries a significant morbidity and mortality rate. Given that abuse often has a transgenerational character, early recognition and intervention with at-risk families have a preventive character in relation to the next generation.

Key words: Physical abuse - Children - Physician's role

\section{Introduction}

Fifty years ago an American paediatrician Dr. Henry Kempe published a paper about battered child syndrome in the Journal of the American Medical Association. He defined battered child syndrome as "the clinical condition in young children who have received serious physical abuse generally from a parent or foster parent". He also describes the condition as "unrecognized trauma" by radiologists, orthopaedists, paediatricians, and social service workers (1). In the nineteen-eighties Kempe's work was named as one of the 60 most important contributions to American medicine in the 20th century (2). Thanks to this work there is increased 
interest shown by experts and the public to the problem of the abused child. Today the Kempe Centre is one of the leading world centres conducting research, training professionals and developing programs of child protection. It is committed to improving prevention, identification and treatment of abused children (3). Physical abuse of children remains a major social problem, especially because of the consequences that may linger long after the experience of abuse. Unfortunately, there is no single, universally applied definition of child abuse and neglect, which is the additional aggravating factor (4). The most commonly used definition of physical abuse is one that involves the activities of a person who is under the age of 18 , which results in the risk of serious injury, death or serious physical consequences, caused by the persons responsible for protecting the child who is under the age of 18 . However, participants are not only those who physically hurt the child, but also those who failed to prevent injury. Perpetrators of abuse are not necessarily adults, but it is essential that there is a disparity in power between the perpetrator and the victim (5).

\section{The prevalence of physical abuse of children}

The war and transition substantially increased the socio-environmental risk of domestic violence and child abuse and neglect (6). All these changes have contributed to a substantial increase in the number of detected or reported cases. According to data from the Ministry of the Interior of the Republic of Croatia, there were thirty times more reports of child abuse and neglect in 2000 than in 1991 (7). Studies have shown that $90 \%$ of American parents spank their 3 and 4 year old children, $22 \%$ of them spank their toddler-age children, $75 \%$ of parents spank their 9 and 10 year old children, $20 \%$ of parents spank adolescents (5). The largest percentage of abused children are between the ages of 4-7 $(28 \%)$ while the proportion of children up to 3 years should not be ignored (17\%). It is the same percentage of children aged 8-11 (17\%), while $22.5 \%$ of 12 to 15 year olds are abused, which lead to a rapid decrease (8). In 2006, the Centre for Child Protection of the City of Zagreb and the "Brave Telephone" hotline conducted the second anonymous survey of over 4000 adult students. The survey found that more than $30 \%$ of the subjects had been physically abused (9). A survey conducted in Croatia, in the framework of research on the intergenerational transmission of abuse in students at the University of Zagreb, showed that out of 1146 students, $93 \%$ of them experienced at least one form of physical violence from their parents in their family before the age of 18 (10). $52 \%$ of respondents who participated in a study conducted in Bosnia and Herzegovina, in the area of the West Herzegovina County, were exposed to some form of physical abuse by the age of 14 (11). These results should always be seen through the prism of fear of recognition, even though the survey was anonymous (12).

\section{Indicators of physical abuse}

Non-accidental injuries should be suspected when an injury is unexplained, the severity of the injury is incompatible with the history, the history keeps changing, or the injury is inconsistent with the developmental age of the child. Any delay in seeking medical care following an injury is also suspected of abuse. In the USA, about $10 \%$ of children under the age of 5 visit Department of Emergency Medical Services as a result of non-accidental injuries (13). Physical abuse includes injuries that are the result of deliberate acts against a child or failure to prevent them. The spectrum of injuries includes the following: 
mechanical injury (bruises, fractures, internal injuries.) and thermal injury (burns).

\section{Bruises}

The most common manifestations of physical abuse are bruises. A bruise is caused by blood that has escaped from damaged capillaries into the interstitial tissues after applying blunt force. It is the process of haemoglobin degradation and its expression through the "window" of the skin that determines the colour of a bruise (14). The estimated age of bruises should never be the sole criteria for a diagnosis of child abuse, but rather part of a comprehensive evaluation that includes a careful history of injuries, family history, associated risk factors, a detailed physical examination and appropriate laboratory tests (15). Estimates of the age of a bruise are currently based on an assessment of the colour of the bruise with the naked eye (red $=2$ days, blue-purple $=2-5$ days, 5-7 days $=$ green, yellow $=7-10$ days; brown $=10-14$ days), but physicians should be aware of age restriction analysis of the bruise (15). The presence of various age bruising is suspicious. Of course, the physician must describe the size, shape, position and colour of each bruise accurately. This is best done by a detailed description and photographing the changes (16). Bruises on relatively protected places such as the upper arms, medial and rear thighs, arms, torso, cheeks, ears, neck, genitals and buttocks, should raise suspicion of abuse, especially if they are extensive and there are bruises of different ages (17). Bruises are extremely rare in children younger than 6 months, because they do not move about. Another useful indicator is the form of bruises, which can indicate the shape of the object with which the injury was inflicted. Multiple bruises in clusters, in an unusual location, bruises located away from bony prominences, bruises in children younger than 9 months, bruises in various stages of healing, and further injury and damage may provide valuable information for distinguishing intentionally inflicted from accidental injury (18). There are many conditions that can mimic bruises, so we must think about the differential diagnosis of: Mongolian spots, blue mole, bleeding disorders, hypersensitivity vasculitis, infections, connective tissue diseases, erythema nodosum, phytophotodermatitis, hemangioma and incontinence of pigment (18).

\section{Fractures}

Fractures are the second most common findings in physically abused children, following skin damage, such as bruises and contusions (19). Fractures are documented in $11-55 \%$ of physically abused children (20). In most cases, there are no external physical findings, such as bruises or hematoma (21). Each fracture in children younger than one year of age should arouse suspicion of abuse (22). About 50\% to $60 \%$ of fractures in children under the age of 1 are the result of abuse (23). Metaphyseal lesions, broken shoulder blade, ribs (especially posterior), sternum, and spinous extensions suggest the presence of abuse (24). Caffey introduced the term "bucket-handle", which describes a metaphyseal fracture of long bones, which is typical for a case of physical abuse of a child (25). This type of fracture is usually located in the distal part of the femur, the proximal and distal part of the tibia / fibula and the proximal part of the humerus (26). This type of fracture will not occur from a blow, but during the traction and torsion of a limb. Another sure sign of abuse is the presence of multiple rib fractures, which can be found in $5-27 \%$ of cases of abuse (27). A retrospective study conducted by Barsness and associates (28), showed that multiple rib fractures are often found in cases of child abuse, and rear and side rib fractures $(78 \%)$ were most likely to be seen. Identified multiple fractures or different age fractures are indications that this is not an 
isolated case of abuse. Head bone fractures in infants, as a result of accidental trauma, are mostly simple, one-sided, linear and usually located in the area of the parietal bone. Most often they occur when a child falls out of the cradle, off a sofa, downstairs ... and produce a relatively minor trauma (29). Fractures that result from abuse are often complex, multiple, bilateral, they cross suture lines and they are associated with intracranial injury (30). On the one hand fractures are a sign of abuse, but on the other hand they are very often the result of accidental trauma, which means that it is necessary to interpret the type and location of fracture with the clinical history, performed by an experienced and trained radiologist (31).

\section{Burns}

Burns can result from exposure to several possible sources, including hot fluid (steam), hot objects or flames, chemicals and electricity. Burns are found in approximately $6 \%$ to $20 \%$ of all cases of child abuse (32). As a result of physical abuse, burns are more often found in children under the age of 3. (17). Characteristic features of burns caused by forced immersion in hot liquid are symmetry, clear lines of demarcation, the unique depth of burns and they usually include the buttocks, perineum, and lower extremities (33). Burns with a "sock-like" or "glove-like" appearance on the hands or feet are usually caused by either dipping or forcing the child to sit in scalding liquid, which results in a symmetrical, circumferential and clearly limited burns (34). One of the most common forms of abusive burns are cigarette burns. Cigarette burns appear in the form of clearly limited circle of 7-10 $\mathrm{mm}$ in diameter, with a deep central crater. They are usually found in groups on the face, arms and legs (35). Accidental burns are non-uniform in depth and usually have irregular borders, as a result of the struggle to escape from the hot liquid (17). A child with abusive burns may have additional signs of abuse e.g., bruising, fractures and a history of previous burns. Studies have shown that any injury, in the case of burns, where there is a delay of more than 2 hours in seeking appropriate medical care, is probably child abuse (17).

\section{Head trauma}

Head trauma is the leading cause of death in abused children (36). Head trauma as a result of physical abuse is most common in children under 6 months (37). The classical finding of violent head trauma is subdural hematoma, brain edema, and retinal haemorrhage (22). Caffey described the "whiplash shaken infant syndrome," in which he noted the mechanism of subdural and retinal bleeding. During violent shaking of a child the rotational acceleration force affects the child's head, resulting in rupture of bridging blood vessels in the subdural space, and damaging retinal capillaries (38). The child may have symptoms such as: lethargy, refusal to eat, irritability, vomiting, convulsions, respiratory changes, or changes in the level of consciousness. Symptoms vary depending on the severity of the injury. Retinal haemorrhages are present in $60 \%$ to $95 \%$ of children with an abusive head injury (37). In head trauma it is necessary to perform laboratory tests, including: complete blood count and coagulation factors, radiographic skull, and computed tomography (CT) of the brain is recommended. If the $\mathrm{CT}$ findings are equivocal or normal with the presence of neurological injuries, magnetic resonance imaging (MRI) should also be performed (39).

\section{Abdominal injury}

Abdominal injuries are the second leading cause of death in abused children $(22,40)$. Visceral manifestations of abuse are rare and 
occur in $2-4 \%$ of cases of abuse (41). Most commonly, children who sustain severe nonaccidental abdominal trauma are between the ages of 6 months and 3 years of age (42). In the use of blunt force to the abdominal area, the duodenum, the jejunum, pancreas and liver may be damaged, while colon and rectal injuries are often associated with sexual abuse (43). The symptoms are often vague, they include irritability, vomiting, lethargy, abdominal distension, anaemia or shock (22, 40). The treatment should include: complete blood count $(\mathrm{CBC})$, biochemistry including liver and pancreatic enzymes, abdomen and thorax X-Ray, and ultrasound and computed tomography scans (CT) of the abdomen.

\section{Munchausen syndrome by proxy}

Munchausen syndrome by proxy is a form of child abuse in which a caregiver induces real or apparent symptoms of a disease in a child. This syndrome almost always involves a mother abusing her child by seeking unneeded medical attention for the child. Munchausen syndrome by proxy (MSbP) reflects maternal psychopathology (44). In the medical history we find frequent hospitalization of the child in various hospitals, with no clear discharge diagnoses. Most often the child is hospitalized with symptoms of poisoning, recurrent attacks of loss of consciousness or asphyxiation. Clinical images are often unusual, bizarre, making it difficult to diagnose. Characteristically the symptoms only occur during periods when the adult who cares for the child has access to the child (at home, in the hospital during or immediately after visits etc.), and never occur in situations when other people take care of the child (45).

\section{Risk factors for child physical abuse}

The exact reason for child physical abuse is not known. There is a whole range of social, psychological, economic, and environmental risk factors. However, it is difficult to predict exactly what will lead to violence. Often, there is evidence that family stress, accompanied by a "trigger" event leads to abuses. Newberger pointed the following three categories as predispositions to stress (46):

- The child's characteristics: disability, learning difficulties, behavioural problems, adoption

- Characteristics of the parents: mental illness, alcohol or drug abuse, domestic violence, pre abused as a child.

- Socioeconomic characteristics: single parents, new parents, new partner, poverty, unemployment.

Here it should be noted that the above risk factors are not causes, but characteristics and circumstances that may favour the occurrence of child abuse and neglect. It does not necessarily occur in the presence of these factors, and it can also occur without their presence (47).

\section{Duties of a doctor in cases of child abuse - treatment protocol}

Despite the discomfort caused by the thought that a child might be abused by the people closest to him, the child care physician has to take this possibility into account, especially when the possible signs, conditions or discrepancy findings and history make this diagnosis unlikely. According to the Criminal Procedure Act of the Federation of Bosnia and Herzegovina, health workers, teachers, educators, parents, foster parents, adoptive parents and other persons, who are authorized and obligated to provide protection and assistance to minors, also have educational and surveillance functions towards them. If there is any reasonable suspicion that the minor has been the victim of sexual, physical or any other form of abuse, they shall immediately notify the suspicion to the authorized 
official or the prosecutor (48). In 2007, a protocol was signed to help the victims of violence in Mostar (12). The protocol includes a number of specific measures which the authorities must follow precisely when providing assistance and protection to persons exposed to any form of violence. This applies to both healthcare professionals and healthcare facilities:

Health care facilities are required to provide the victim comprehensive health care, in order to preserve the physical and mental health of the victims, and allow recovery from injuries and trauma. In cases where violence has been committed, especially domestic violence, health care workers are required to do the following:

- Immediately inform the police and the centre about the violence;

- Determine the causes of the injury and do a complete health check-up;

- In the case of personal injury, a report should be kept in a separate protocol for patient injury and a file;

- At the request of the competent prosecutor or the court, the health institution shall promptly submit all documentation essential for elucidation of domestic violence;

- If the victim of violence is a person with a mental illness or who has been treated for alcoholism and other addictions, they may be referred to treatment and compulsory hospitalization and the centre and the police notified;

\section{References}

1. Kempe CH, Silverman FN, Steele BF, Droegmueller W, Silver HK. The battered-child syndrom. JAMA. 1962;18:17-24.

2. Mujkić A. The Abused and Neglected Child-the Physician Role [in Croatian]. Pedijatrija danas. 2007;3(2):209-18.

3. How the story of recognizing and protection of
- If the abuser is a person with a mental illness or who has been treated for alcoholism and other addictions, they may be referred for treatment and compulsory hospitalization and the centre and the police notified. Before release, the health care provider must inform the centre.

\section{Conclusion}

Physical abuse of children is a common occurrence, and it carries a significant morbidity and mortality rate. Physicians must be able to recognize abuse and to take appropriate measures to protect children. Given that abuse often has a transgenerational character, early recognition and intervention with at-risk families have a preventive character in relation to the next generation. The state should ensure that everyone is familiar with the rights of children and understands those rights, including children. Public information campaigns should be used to sensitize the public about what harmful effects bullying may have on children. We must be careful to confront social and cultural attitudes and actions that clearly violate human rights because of their adherence to tradition.

Conflict of interest: The author declares that she has no conflict of interest. This study was not sponsored by any external organization. abused children started? [in Croatian]. [cited 2012 November 17]. Available from: http://www.insideout.hr/o-obitelji/djeca/

4. Buljan-Flander G, Karlović A, Matijević-Vrsaljko Lj. Manual „25 questions (and answers) about the procedures for the experts in the detection of child abuse“ [in Croatian]. Poliklinika za zaštitu djece grada Zagreba; 2003. 
5. Buljan-Flander G, Kocijan-Hercigonja D. Child abuse and neglect [in Croatian]. Zagreb: Marko M; 2003.

6. Ždero V. Psychological Abuse and Neglect of children in the family [in Croatian]. Ljetopis socijalnog rada. 2005;12(1):145-72.

7. Buljan Flander G, Ćosić I. Recognizing and symptomatology of child abuse and neglect [in Croatian]. Medix. 2003;51:122-24.

8. Žegarac N. Deca koja čekaju: Challenges and trends of professional practice in the protection of children from abuse [in Serbian]. Beograd: Beogradska kancelarija, Centar za prava deteta; 2004.

9. Buljan Flander G. The exposure of children to violence: Have we learned something? [in Croatian]. In: V. Kolesarić, editor. Psychology and violence in modern society [in Croatian]. Zbornik radova znanstveno-stručnog skupa Psihologija nasilja i zlostavljanja. Osijek: 2007.

10. Pećnik N. Towards rejection of corporal punishment of children [in Croatian]. Dijete i društvo. 2006;8(1):177-99.

11. Sesar K, Zivcic-Becirevic I, Sesar D. Multi-type maltreatment in Childhood and Psychologicaladjustment in Adolescence: Questionnaire Study Among Adolescent in Western Herzegovina Canton. Croat Med J. 2008;49:243-56.

12. How to recognize violence against children and help the child victim of violence handbook for professionals [in Croatian]. [cited 2012 November 15]. Available from: http://www.zenabih.ba/ download/djeca_nasilje.pdf

13. Hyden PW, Gallagher TA. Child abuse intervention in the emergency room. Pediatr Clin North Am. 1992;39:1053-81.

14. Cotran RS, Kumar VK, Robbins SL. Ceuular injury and adaptation. In: Cotran RS, Kumar VK, Robbins SL, eds. Robbins Pathologic Basis of Disease. 5th ed. Philadelphia: VVB Saunders Co; 1994. p. 28-29.

15. Schwartz J, Ricci LR. How accurately can bruises be aged in abused children? Literature review and synthesis. Pediatrics. 1996; 97:254-7.

16. Ricci LR. Photographing the physically abused child: principles and practice. Am J Dis Child. 1991;145:275-81.
17. Kos L, Shwayder T. Cutaneous manifestations of child abuse. Pediatr Dermatol. 2006;23:311-20.

18. Swerdlin A, Berkowitz C, Craft N. Cutaneous signs of child abuse. J Am Acad Dermatol. 2007;57:37192.

19. Maguire S, Mann MK, Sibert J, Kemp A. Are there patterns of bruising in childhood which are diagnostic or suggestive of abuse? A systematic review. Arch Dis Child. 2005;90:182-6.

20. Kirks DR. Radiological evaluation of visceral injuries in the battered child syndrome. Pediatr Ann. 1983;12(12):888-93.

21. Mathew MO, Ramamohan N, Benet GC. Importance of bruising associated with paediatric fractures: prospective observational study. BMJ. 1998;317(7166):1117-8

22. Herendeen P. Evaluation of physical abuse in children: Solid suspicion should be yourguide. Adv Nurse Pract. 2002;10(8):32-6.

23. Willman KY, Bank DE, Senac M, Chadwick DL. Restricting the time of injury in fatal inflicted headinjuries. Child Abuse Negl. 1997;21(10):929-40.

24. Nimkink K, Kleinman PK. Imaging of child abuse. Radiol Clin North Am. 2001;39(4):843-64.

25. Hobbs CJ, Hanks HGI, Wynne JM. Clinical aspects of sexual abuse. In: Child abuse and neglect. A clinical handbook. Edinburg: Churchill Livingston. 1993; p.139-94.

26. Kleinman PK, Marks SC., Jr. Relationship of the subperiostal bone collar to metaphyseal lesions in abused infants. J Bone Joint Surg Am. 1995;77(10):1471-6.

27. Cramer EC. Ortopedic aspetcs of child abuse. Orthop Clin North Am. 1996;43:1035-51.

28. Barsness KA, Cha ES, Bensard DD, Calkins CM, Partrick DA, Karrer FM, Strain JD. The positive predictive value of rib fractures as an indicator of nonaccidental trauma in children. J Trauma. 2003;54:1107-10.

29. Brodgon BG. Child abuse. In: Brodgon BG, editor. Forensic radiology. Boca Raton: CR C Press,1998:281-314.

30. Carty H. Non-accidental injury: a review of the radiology. Eur Radiol. 1997;1365-76.

31. Kremer C, Racette S, Marton D, Sauvageau A. Radiographs interpretation by forensic pathologists: 
a word of warning. Am J Forensic Med Pathol. 2008;29(4):295-6.

32. Peck MD, Priolo-Kapel D. Child abuse by burning: a review of the literature and a algorithm for medical investigations. J Trauma. 2002;53:1013-22.

33. Jain AM. Emergency department evaluation of child abuse. Emerg Med Clin North Am. 1999;17:575-93.

34. Yeoh C, Nixon JW, Dickson W, Kemp A, Sibert JR. Patterns of scald injuries. Arch Dis Child. 1994;71:156-8.

35. Hobbs CJ. When are burns not accidental? Arch Dis Child. 1986;61:357-61.

36. Smith J. Shaken baby syndrome. Orthop Nurs. 2003;22:196-203.

37. Listman DA, Bechtel K. Accidental and abusive head injury in young children. Curr Opin Pediatr. 2003;15(3):299-303

38. Caffey J. On the theory and practice of shaking infants: Its potential residual effects of permanent brain damage and mental retardation. Am J Dis Child. 1972;124(2):161-9.

39. American Academy of Pediatrics. Shaken baby syndrome: rotational cranial injuries technical report. Pediatrics. 2001;108:206-10.

40. Kini N, Lazoritz S. Evaluation for possible physical or sexual abuse. Pediatr Clin North Am. 1998;45(1):205-19.
41. Merten DF, Carpenter BLM. Radiologic imaging of inflicted injury in the child abuse syndrome. Pediatr Clin North Am. 1990;37:815-37.

42. Mayer BW, Burns P. Differential diagnosis of abuse injuries in infants and young children. Nurse Pract. 2000;25(10):15-37.

43. $\mathrm{Ng} \mathrm{CS}$, Hall CM, Shaw DG. The range of visceral manifestations of nonaccidental injury. Arch Dis Child. 1997;77:167-74.

44. Bools C, Neale B, Meadow R. Munchausen syndrome by proxy: a study of psychopathology. Child Abuse Negl. 1994;18(9):773-88.

45. Parnell TF. Munchausen by Proxy Syndrome. In: Myers J, Berliner L, Briere J, Hendrix C, Jenny C, Reid T, editors. The APSAC Handbook on Child Maltreatment. 2nd ed. California: Sage Publications; 2002. p. 131-138.

46. Newberger EH. Child physical abuse. Primary Care. 1993;20:317-27.

47. Child protection from abuse and neglect Applying General Protocol [in Serbian]. [cited 2012 November 10]. Available from: http://www.cpd.org.rs/ dokumenti/Primena_Opsteg_protokola_Zastita_deteta.pdf

48. Criminal Procedure Act of Federation of Bosnia and Herzegovina [in Croatian]. [cited 2013 January 9]. Available from: http://www.oss.ba/dokumenti/ZKP_FBIH.pdf

Citation: Mikulic M, Jurisic K. The physician's role in recognizing physical abuse of children. Paediatrics Today. 2013;9(1):64-71. 